\title{
EMERGENCY GOVERNANCE (UN)BOUND: A BRIEF REFLECTION ON SOUTHEAST EUROPE'S RESPONSE TO COVID-19 PANDEMIC
}

\begin{abstract}
Relying on the Madison-Schmitt dichotomy in the theory of emergency governance, this article will explore to what extent constitutional courts of Southeast Europe imposed warranted limits to the executive power in their responses to the Covid-19 global pandemic. The specific aim of this article is to illustrate how the constitutional courts of Croatia and Serbia responded to the question of whether the Covid-19 pandemic called for the introduction of the state of emergency. The dilemmas that emerged in the Covid-19-related rulings of these courts reflect the heated constitutional theoretical debates on emergency powers, which could be roughly reduced to three main points of examination: (1) Is the executive de facto Schmitt's sovereign, who decides on the case of exception even when the constitution states otherwise? (2) Should the courts, following the historically repetitive practice, demonstrate special deference to other branches of government in the time of crisis such as the Covid-19 pandemic? (3) Are the courts in the position to assess the constitutionally envisaged facts and conditions for introducing the emergency regime, e.g., to go into a formal and substantive review of the declaration of the state of emergency? The analysis will conclude that the constitutional courts of Serbia and Croatia failed to set out a robust doctrine of emergency powers and constrain other branches of governments effectively. In Serbia, that resulted in a constitutionally legitimized Neo-Schmittian model, which presupposes that in the time of a crisis, the powers of emergency decision-making significantly shift to the executive. On the other hand, the Croatian Constitutional Court missed the chance of entrenching a strong Madisonian model based on the interbranch checks and balances and cooperation.
\end{abstract}

Key words: Covid-19, constitutional courts, emergency powers, state of emergency, judicial review.

\section{INTRODUCTION}

The severity of the Covid-19 global pandemic significantly changed the perceived role of the state in liberal constitutional democracies but

SJD candidate, Central European University PU, Legal Studies Department, Vienna/ Budapest; e-mail: Miljojkovic_Teodora@phd.ceu.edu 
also tempered with the principle of check and balances in the response to a public emergency "threatening the life of the nation". ${ }^{1}$ Ultimately, the pandemic put the liberal constitutionalism at test. Countries worldwide simultaneously undertook various steps to respond to the emerging exigencies, which resulted in limitations to both substantive and procedural rights under the existing public safety frameworks. With the surge of regulation, courts all around the world faced the challenge of monitoring and assessing the legality and constitutionality of governmental measures. For example, El Salvador's Supreme Court suspended President's Nayib Bukele's state of emergency decree which aimed to extend the state of emergency without the authorization of the Congress, finding the emergency decree contrary to Article 2 of the El Salvador's Constitution. ${ }^{2}$ In addition to the assessment of the new regulation, mostly legislative in nature and adjusted to the particularities of the times of pandemic, the courts got the chance to examine how the core norms of the already existing constitutional emergency powers framework may be used and abused in practice.

The aim of this article is to shed light on the assessment of the constitutional courts' responses to the governments' decision to introduce (or not introduce) the state of emergency in Serbia and Croatia. The courts' rulings are particularly important as they tackle one of the most important questions in the theory of emergency powers - which branch of government is competent to respond to the times of crisis? To provide an answer, the article will rely on the theoretical distinction between Madisonian and Neo-Schmittian emergency governance theories, offered by Tom Ginsburg and Mila Versteeg in their recent discussion on judicial responses to the COVID-19 emergency management. ${ }^{3}$ To grasp the essential dilemma behind the contrasted models, it is useful first shortly to refer to the grounding rationales behind the emergency governance theories.

1 Council of Europe, European Convention for the Protection of Human Rights and Fundamental Freedoms, as amended by Protocols Nos. 11 and 14, 4 November 1950, ETS 5 , Article 15. On further analysis of the definition of the "public emergency threatening the life of the nation", see: Greene, A., 2019, Separating Normalcy from Emergency: The Jurisprudence of Article 15 of the European Convention on Human Rights, German Law Journal, Cambridge University Press; also Beširević V. et al., Član 15 Odstupanje u vanrednim okolnostima, in: Beširević et al., 2017, Komentar Konvencije za zaštitu ljudskih prava i osnovnih sloboda, Službeni glasnik.

2 Decision on Unconstitutionality of the Supreme Court of El Salvador (Inconstitucionalidad) of May 18 2020, Official Gazette, 69/20.

3 Ginsburg, T., Versteeg, M., 2020, The Bound Executive: Emergency Powers During the Pandemic, Virginia Public Law and Legal Theory Research Paper No. 2020-52, University of Chicago, Public Law Working Paper No. 747. 


\section{Do All Emergencies Lead to Schmitt?}

The established literature and the existing designs of modern constitutions put forward two models of state of emergency: the executive model and the legislative model. The executive model provides for the wide power of the executive which often goes hand in hand with wide discretion, in terms of lack of checks by other branches of the government. The tendency to give the emergency powers and particularly right to declare a state of emergency to the executive predates modern constitutions and it has remained prevalent up to date. An example of a constitutional design which reflects this model can be found in Article 16 of the 1958 French Constitution. More recent example of the vast executive's emergency powers can be found in the Turkish Constitution after 2017 amendment, which gave the President the power to declare state of emergency on quite vague and numerous grounds.

The modern constitutions, however, impose several important constrains on the executive power: the requirement of approval of President's declaration, decrees or introduced measures by the legislative branch, the time-limit and, following international standards (notably the International Covenant on Civil and Political Rights) prohibition of derogation of certain rights and freedoms and the requirement that emergency measures be proportionate or "strictly required by the exigencies of the situation." 4

Unlike the executive model, whose traces can be found already in the Roman Empire, the legislative model was developed in the other half of the twentieth century in stable democracies. ${ }^{5}$ According to John Ferejohn and Pasquale Pasquino, in the legislative model the legislature not only "handles emergencies by enacting ordinary statutes that delegate special and temporary powers to the executive" but also "the legislature plays a fundamental role both in recognizing an emergency and in creating the powers to deal with it". ${ }^{6}$ Despite the appearance of flexibility that the legislative model has in comparison to the republican (Roman) model, it carries certain dangers as well. ${ }^{7}$

4 Art. 4, UN General Assembly, International Covenant on Civil and Political Rights, 16 December 1966, United Nations, Treaty Series, Vol. 999, p. 171, (https://www.refworld.org/docid/3ae6b3aa0.html, 1. 4. 2021).

5 Ferejohn, J., Pasquino, P., 2004, The Law of the Exception: A Typology of Emergency Powers, International Journal of Constitutional Law, Vol. 2, No. 2, p. 216.

$6 \quad$ Ibid., p. 217.

7 Ferejohn and Pasquino offer several possible shortfalls of the legislative model: "For one thing, the legislature may be unready or unwilling to act in a timely fashion. Second, even if the legislature is willing to enact emergencies laws, that very action may implicate it in the conduct of emergency rule and eliminate a valuable check 
Finally, every state of emergency raises the question of what latitude the judicial power has in constraining the government when departing from ordinary times? Other than theorists' skeptical stands on courts' role in times of emergency, whose views will be illustrated further in this article, the opposing views are also present within the literature. For example, David Dyzenhaus claims that "the legislature and the executive have that same duty to uphold the rule of law in emergency times no less than in ordinary times, which is why judges are entitled to assert the rule of law in the face of what seem to be legislative or executive indications to the contrary". 8 Indeed, many constitutions and judicial precedents do assign to the courts the power to assess the constitutionality of emergency laws and state actions. However, the actual powers of the courts to deal with the delicate question of departure from the "state of normalcy" depend not only on prescribed prerogatives, but also the inter-branch power dynamics which are delineated by local contexts.

In theoretical terms, there is hardly any constitutional theory on emergency governance which does not refer to the notorious Carl Schmitt's claim that "the sovereign is the one who decides on exceptionality". ${ }^{9}$ The view that the emergency time requires a departure from the established order and opens the space for the legally unconstrained government's power was present already in John Lock's Second Treatise of Government, but Schmitt, according to Dyzenhaus, "radicalized" that idea. ${ }^{10}$ Although the Schmittian view that the sovereignty is essentially pre-legal idea and that the government's power is legally unconstrained in times of exception has been vastly disputed in theory, Dyzenhaus notes that "Schmitt is and has to be taken seriously because the claim that the executive is the real agent in responding to emergencies seems to have considerable support in legal and political experience." ${ }^{11}$ Allan Greene recently claimed that "Schmitt is only really useful in analyzing emergency responses to the pandemic if there does not appear to be any legal authority authorizing government

or monitor on the executive. And finally, the laws made to deal with the emergency may become embedded in the normal legal system, essentially enacting permanent changes in that system under color of the emergency". Ibid., p. 219.

8 Dyzenhaus, D., 2006, The Constitution of Law - Legality in a Time of Emergency, Cambridge University Press, p. 4.

9 Schmitt, C., Schwab, G. (transl.), 2006, Political Theology: Four Chapters on the Concept of Sovereignty, University of Chicago Press, chapter I.

10 Lock, J., 1980, Macpherson C.B. (ed.), 1980, Second Treatise of Government, Hackett Publishing, para. 160. Also Dyzenhaus, D., States of Emergency, in: Sajó, A., Rosenfeld, M., (eds.), 2012, The Oxford Handbook of Comparative Constitutional Law, Oxford University Press, p. 443.

11 Ibid., p. 445. 
action. If there is law, Schmitt is not very helpful at all." 12 This claim supports his previously expressed position that "the power to declare a state of emergency, while exceptional in the sense that it should be exercised rarely, must nevertheless be located within the legal order. The body exercising emergency powers must respect the constitutional constraints on the exercise of that power and, logically, there must also be constraints on this power for it to be legal." 13

Worth mentioning here is Bruce Ackerman's distinction of the court's engagement into macromanagement and micromanagement of the emergency regimes. Macromanagement, according to Ackerman, concerns the integrity of the emergency regime as a whole contemporaneously, while micromanagement presupposes the constitutional review of emergency measures upon individual claims of rights violations which follow from the state of emergency introduced. ${ }^{14}$ While Ackerman essentially called for an active role of the courts in monitoring the government during emergency, he primarily referred to the micromanagement while he remained "skeptical about the wisdom of immediate judicial intervention". ${ }^{15}$ It should be noted that Ackerman was construing his arguments in regard to the case of terrorist attacks as grounds for the introduction of emergency regime and his focus was primarily on the US.

Now, aiming to reassess the common theoretical position on the role of the executive in the state of emergency, Ginsburg and Versteeg have offered their own typology of emergency powers: Neo-Schmittian model and Madisonian model. This distinction is essentially a response to Adrian Vermuele's and Eric Posner's typology which differentiates Schmittian and Post-Madisonian model. ${ }^{16}$ Ginsburg and Versteeg claim that the conventional wisdom of the necessity for the unbound executive in times of emergency actually might be challenged. ${ }^{17}$ What these authors call Neo-Schmittian theory is essentially the position advocated by Vermuele

12 Greene, A., 2020, States should declare a State of Emergency using Article 15 ECHR to confront the Coronavirus Pandemic, Strasbourg Observers, (https://strasbourgobservers.com/2020/04/01/states-should-declare-a-state-of-emergency-using-article15-echr-to-confront-the-coronavirus-pandemic/, 7. 10. 2020).

13 Greene, A., 2018, Permanent States of Emergency and the Rule of Law: Constitutions in an Age of Crisis, Hart Publishing, p. 78.

14 Ackerman, B., 2004, The Emergency Constitution, Yale Law Journal, 113, p. 1066.

15 Ibid. "If the President can convince a majority of the legislature of the need for emergency powers, this should suffice. At this early stage, we should rely on the legislature, not the judiciary, to restrain arbitrary power."

16 Posner, E., Vermuele, A., 2011, The Executive Unbound: After the Madisonian Republic, Oxford University Press.

17 Ginsburg, T., Versteeg, M., 2020. 
and Posner which presupposes that, in the times of the national threat, the executive is the only branch of government capable "with the resources, power, and flexibility" to balance civil liberties against security in the face of an emergency. ${ }^{18}$ With regard to the role of the courts, Vermuele and Posner emphasize that the courts "should defer to government action so long as there is any rational basis for the government's position" as the judicial review "cannot improve matters, because there is no reason to think that courts possessing limited information and limited expertise will choose better security policies than does the government". ${ }^{19}$ Vermuele and Posner do put limitation to the applicability of their theory outside the US context. ${ }^{20}$ However, the essence of their arguments reflects not only other theoretical views, but also courts' reasoning worldwide.

Unlike Neo-Schmittian model, the Madisonian model presupposes the "scheme of checks and balances, wherein different branches and levels of government have the incentives to keep each other in check". ${ }^{21}$ While Vermuele and Posner held the Madisonian model, drawn from Federalist 51 , as unsustainable in the emergency times, Ginsburg and Versteeg claim the opposite.

In order to practically show how Madisonian model works, Ginsburg and Versteeg have surveyed the available data on courts responses to Covid-19 measures introduced by governments worldwide. Basing their claims on the empirical survey on the courts' responses to the pandemic from more than hundred jurisdictions worldwide, the authors concluded that "the picture that emerges, is not one of an unbound executive but one of Madisonian constraints, in which governmental institutions interact, both cooperatively and through conflict, in determining as to how to handle a crisis." ${ }^{2}$ Considering the Madisonian model, Ginsburg and Versteeg argue that both Parliament and the courts should impose effective constrains on the executive power. For the purpose of this paper, particularly important is their focus on judicial power. Having in mind the focus of

18 Posner, A., Vermuele A., 2007, Terror in the Balance: Security, Liberty and the Courts, New York, Oxford University Press, 2007, p. 4.

19 Ibid., p. 12.

20 "An implication is that the demise of liberal legalism, of the separation of powers, even of the rule of law itself, need not imply autocracy; across nations, a wealthy and educated population is a strong safeguard of democracy, according to empirical evidence we will review. The critics of the imperial presidency focus to excess on the role of law in constraining the executive, assuming that the only alternative is tyranny, but this is an unjustified belief, given the evidence-akin to a fear of genetically modified foods." Posner, E., Vermuele, A., 2011, p. 16.

21 Ginsburg, T., Versteeg, M., 2020, fn. 16, p. 4.

22 Ibid., p. 56. 
the courts, Versteeg and Ginsburg have offered the following classification of judicial review: (1) procedural judicial review, in which the focus of the courts is on the assessment of the formal requirements for the governmental actions laid out in relevant legislation and constitution itself; (2) substantive judicial review, in which the courts deal with the procedure and the rationality and constitutionality of the governmental measures; (3) the "advanced" judicial review in which the courts take a step further and request from the government specific measures to be implemented. ${ }^{23}$

In the rest of this article, following two models of emergency powers offered by Ginsburg and Versteeg, I will show that the Serbian Constitutional Court's decision confirms Neo-Schmittian model, while the Croatian Court, although with some hesitation, has supported Madisonian model.

\section{The Serbian Constitutional Court AND THE Lineages of Judicial Deference}

The Serbian Constitution vests the power to declare the state of emergency to the National Assembly. ${ }^{24}$ However, Article 200 of the Constitution envisages that "when the National Assembly is not in a position to convene, the decision proclaiming the state of emergency shall be adopted by the President of the Republic together with the President of the National Assembly and the Prime Minister, under the same terms as by the National Assembly." ${ }^{25}$ Accordingly, if the National Assembly is not able to meet in session, "all the measure which provide for derogation from human and minority rights may be prescribed by the Government, in a decree, with the President of the Republic as a co-signatory." ${ }^{26}$

The state of emergency due to Covid-19 pandemic was declared in Serbia by the decision signed by the President of the Republic, the Prime Minister and the President of the National Assembly on March 15, 2020

23 Ibid., p. 5. The theoretical typology offered above can serve as a useful working model for the jurisprudence analysis, but in practice, the distinctions between three types of decisions delivered by the courts may get blurred, as the requests for a formal and substantial review of Covid-19 related governmental actions can also be brought before constitutional courts as intertwined and co-dependent or merged into a single decision by the courts themselves.

24 See Article 200 of the Constitution of the Republic of Serbia, Official Gazette of RS, No. $98 / 06$.

25 Ibid.

26 See Article 200. 
on the basis of Article 200 (2) of the Serbian Constitution. ${ }^{27}$ The Serbian Constitutional Court faced several motions to assess the constitutionality of the proclaimed state of emergency. ${ }^{28}$ In principle, the motions put forward two main claims: (1) the Covid-19 pandemic does not require the proclamation of the state of emergency, but the proclamation of emergency situation envisaged in the Serbian legislative framework (including the Law on Public Health, ${ }^{29}$ the Law on the Protection of the Population from Infectious Diseases ${ }^{30}$ and the Law on Disaster Risk Reduction and Emergency Management ${ }^{31}$ ); (2) even if the state of emergency had to be proclaimed, the executive act, issued after the National Assembly declared that it could not meet in session due to the pandemic, could not limit nor prevent the National Assembly to perform its constitutional task, as it would be contrary to the principles of the rule of law and separation of powers. ${ }^{32}$

The Constitutional Court dismissed motions for the constitutional review on the procedural grounds. It should be emphasized that the reliance on procedural grounds to avoid deciding the questions of crucial constitutional importance is not a novelty in the jurisprudence of the Serbian Constitutional Court. ${ }^{33}$ Yet, although it dismissed the motions, the Court used the opportunity to enter into substantive discussion as well, which, again, is a long-standing manner of its politics. Here, I will not consider the issue of whether the constitutionally envisioned conditions

27 Decision on the Declaration of the State of Emergency of 15 March 2020, Official Gazette of RS, 29/20.

28 Constitutional Court of the Republic of Serbia, Ruling on Dismissal IUo-42/2020 of May 22, 2020, Official Gazette of RS, No. 77/20.

29 The Law on Public Health, Official Gazette of RS, No. 15/16.

30 The Law on the Protection of the Population from Infectious Diseases, Official Gazette of RS, No. 15/16, 68/20, 136/20.

31 The Law on Disaster Risk Reduction and Emergency Management, Official Gazette of RS, No. 87/18.

32 In regard to the pandemic was the reason for the Parliament not to meet in session, petitioners claim that such an argument is legally unacceptable, because the Order on the Declaration of the Covid-19 pandemic (Official Gazette of RS, No. 31/20) was legally enforced only after the Parliament's decision not to meet. The petitioners further claim that the provision on the prohibition of retroactivity (Article 197 of the Constitution) disallows the National Assembly to justify its decision to meet with the later enforced Declaration. IUo-42/2020, Section I.

33 For example, in the Brussels Treaty Case, the Court asserted itself incompetent to review the Treaty on the procedural grounds, although arguably, strong arguments were coming from legal scholarship that the separation of powers principle and the political question doctrine called for the Court's abstinence. See: Beširević, V., 2016, A jedan razlog menja sve: kontrola ustavnosti Briselskog sporazuma u svetlu doktrine političkog pitanja, Hereticus, No. 1-2, pp. 127-151. 
for the declaration of the state of emergency were present or not in Serbia. Rather, I will concentrate on the reasons which motivated the Serbian Constitutional Court to reject the motions for a constitutional review.

From the procedural point of view, the Court rejected the motions as "constitutionally unfounded" because they "fail to support the claim that there were reasons for the Constitutional Court to assess the declaration of the state of emergency". ${ }^{34}$ The Court's reasoning was rightly brought into question within the scholarship. ${ }^{35}$ As Bojan Spaić reminds, the grounds for dismissal are specifically laid out in the Article 36 of the Law on the Constitutional Court. Thus, the Court may dismiss a motion to initiate or institute a constitutional review proceedings: (1) when it determines that it is not competent to issue a decision; (2) if the motion was not filed within the designated time-limit; (3) if the motion is anonymous; (4) when the submitter had not rectified shortcomings which preclude processing within a designated time-limit; (5) when it determines that the motion is manifestly unfounded; (6) if it determines that the motion represents an abuse of law; and (7) when other preconditions for conducting a procedure and determination do not exist, as established by law. ${ }^{36}$

As the Constitutional Court did not refer to any of the mentioned grounds in the ruling, it is open to interpretation on which ground the motions were dismissed. It seems that the initiatives could have been dismissed only either due to the Court's incompetence or because they were manifestly unfounded. Otherwise, if the ground were purely procedural (e.g. for the reason of untimely submission), the Court would not need to provide any in-depth justification for the decision, as it did in the eleven-pages long ruling. Obviously, the Court found itself competent to decide the case. ${ }^{37}$ Therefore, it can be concluded that the Court found all motions to be manifestly unfounded. As Spaić notes, the problem is that the Court did not explain what "manifestly unfounded motion" stands for. ${ }^{38}$ The legal uncertainty behind the ground of "manifestly unfounded motions" arguably undermines the principle of the rule of law and leaves to the Constitutional Court to decide with a wide discretion which cases will or will not be subject to constitutional review. ${ }^{39}$

34 IUo-42/2020, section V.

35 See: Spaić, B., 2020, Literarni dometi rešenja IUo-42/2020, Center for Judicial Research Cepris, (https://www.cepris.org/licni-stavovi/literarni-dometi-resenja-i\%D1\%83\%D0\%BE42-2020dr/, 12. 11. 2020).

36 Article 36 of the Law on the Constitutional Court, Official Gazette of RS, No. 103/15.

37 Besides, Article 36 also states that if the court is not competent to issue a decision, it may refer the case to the competent authority, which it did not do.

38 Spaić, B., 2020.

39 Article 1 of the Serbian Constitution prescribes that "Republic of Serbia is a state of Serbian people and all citizens who live in it, based on the rule of law and social 
The additional procedural problem is the fact that the Court did not enlist either the names of the petitioners or the contents of the motions. Instead, in the Section I, it has only summarized all arguments from the motions ${ }^{40}$ and referred to them within the ruling in a rather selective and fractioned manner.

As mentioned before, the fact that the motions were dismissed on a procedural ground did not prevent the Court from engaging in a substantive analysis, which has become a relatively frequent Court's habit. Moreover, the Court discussed the merits and introduced the doctrine of the state of emergency in the Serbian constitutional law. Thus, according to the Serbian Constitutional Court, Article 200 of the Serbian Constitution envisages: (1) a constitutional condition for declaring the state of emergency amounting to "public threat to the citizens or the integrity of the state"; (2) the object of the protection - citizens and the state; (3) means or mechanisms to achieve the protection - measures derogating constitutionally protected rights and freedoms; (4) a constitutional aim - efficient and prompt return to the state of constitutional normalcy. ${ }^{41}$ The Court noted that two additional features of the Serbian emergency regime include the temporary nature of the state of emergency (maximum 90 days) and the procedure for the declaration of the state of emergency (constitutionally authorized organ and the decision itself). ${ }^{42}$

Now, even though the Court's reading of Article 200 may be correct, the manner of its application in the present case raises serious concerns both from the constitutional theory perspective and the relevant international standards on emergency powers.

Firstly, in order to show that the first requirement, i.e. conditions necessary for the declaration of the state of emergency, was met in the case of the Covid-19 pandemic, the Court went into the material evaluation assessing the fact that the World Health Organization declared the worldwide pandemic ${ }^{43}$, that the causes and the consequences of the Covid-19 were at the time yet unknown, and that detrimental effects of the pandemic were already present both in Serbia and abroad. ${ }^{44}$ The facts which

justice, principles of civil democracy, human and minority rights and freedoms, and commitment to European principles and values."

40 See: IUo-42/2020, Section I.

41 IUo-42/2020, Section IV, p. 4.

42 Ibid.

43 WHO Director-General's opening remarks at the media briefing on COVID-19 of 11 March 2020. Speech available at https://www.who.int/director-general/speeches/ detail/who-director-general-s-opening-remarks-at-the-media-briefing-on-covid19---11-march-2020.

44 Ibid., Section II, p. 6. 
the Constitutional Court referred to may reasonably amount to a public threat as envisioned by the Article 200 of the Constitution. However, at the same time they arguably may amount to the conditions necessary to declare the emergency situation as laid out in Serbian legislative framework. ${ }^{45}$ On this point, the Court noted that "there is a prevalent position that it is hard, if not impossible, ${ }^{46}$ to make a clear differentiation between the state of emergency and emergency situation" ${ }^{47}$ According to the Court, the differentiating factors would be the intensity of the threat and the estimation whether there is necessity to depart from the state of constitutional normalcy or not. ${ }^{48}$ However, if it is challenging to distinguish between the state of emergency and emergency situation, the real issue is then why the emergency situation is envisioned in the Serbian legislation in the first place. To avoid the wide discretion of the constitutional actors in the estimation of which regime responds more adequately to the factual threat, the Constitutional Court, as the final interpreter of the Constitution, should have set out clear legal standards to be followed in each particular case. In the present case, it failed to do so.

Secondly, the Serbian Constitutional Court also stated that in the time of a crisis "disruption of powers" is "a feature of the state of emergency", while the fact that the powers de facto shift to a great extent to the executive does not undermine the principle of the separation of powers. ${ }^{49}$ Thus, the Serbian Constitutional Court has legitimized the overarching executive's power in times of emergency, in Neo-Schmittian sense. Not only that the constitutional theory cannot support this finding, but the Serbian Constitution itself cannot support it. To remind, the Serbian Constitution is among the $10 \%$ of all the present constitutions which vests the original power to declare a state of emergency in the legislative branch. ${ }^{50}$ If this is so, then the Court's claim that the shift to the executive is justified is based on somewhat shaky grounds.

To summarize, despite its claim that it did not need to assess the facts of the case as the motions for the constitutional review were manifestly unfounded, the Serbian Constitutional Court went into the material review of the conditions relevant for the declaration of the state of emergency. ${ }^{51}$

45 Art. 2, para. 7.

46 Emphasis added by the author.

47 IUo-42/2020, p. 6.

48 Ibid.

49 Ibid., p. 7.

50 Bjørnskov, C., Voigt, S., 2018, The Architecture of Emergency Constitutions, International Journal of Constitutional Law, Vol. 16, No. 1, p. 108.

51 Ibid. It is important to note that the National Assembly did meet on April 29 and affirmed the state of emergency declaration. Having that in mind, it could be argued 
This procedural phenomenon could be arguably justified if the Court has imposed limits to the executive's discretion, as it is the "watchdog" of constitutionally protected rights and freedoms and not of the state itself. The decision obviously served to legitimize the dominance of the executive power during the crisis, proving that the Neo-Schmittian model of emergency governance still prevails in Serbia.

The Croatian case is significantly different. Unlike Serbia, Croatia did not declare a state of emergency due to the Covid-19 pandemic. However, there was a strong view that it should have done so, expressed not only by a significant number of scholars but also by the petitioners who asked the Constitutional Court to rule on this issue. Consider the following.

\section{Croatia: State of Emergency and "Competing Constitutional Norms"}

The Constitutional Court of Croatia dismissed the three requests for the constitutional review of Law on Protection of the Population from Infectious Diseases and the Law on the Civil Protection System. ${ }^{52}$ Both laws were previously amended amid the emergence of the pandemic and vested the powers of introducing the Covid-19 related measures to the Civil Protection Authority. The provision of the amended Law on the Civil Protection System (Article 22a) states:

In case of specific circumstances involving an unpredictable or uncontrollable event or state endangering the lives and health of citizens [...] the Civil Protection Authority renders decisions and guidelines to be implemented by the civil protection authorities of the local and regional governments. Such decisions and recommendations are rendered to protect the lives and health of citizens. ${ }^{53}$

The applicants, in their request, asserted that the powers to introduce measures that severely restrict human rights and liberties guaranteed by the Constitution could not be delegated to the Civil Protection Authority

that in practice, it would not matter as much whether the declaration was made by the National Assembly or the President, Prime Minister, and the President of the National Assembly. However, from the perspective of the protection of the rule of law and constitutionality, the question of who, in fact, is authorized to declare the state of emergency makes all the difference.

52 The Constitutional court of Croatia, the Ruling on Dismissal U-I-1372/2020 of $14^{\text {th }}$ September 2020, National Gazette of RC, No. 105/20. Law Amending the Law on the Civil Protection System, National Gazette of RC, 82/15, 118/18, 31/20, Law on the Protection of Population from Infectious Diseases, National Gazette of RC, No. 47/20. Ibid. Art. 22. 
as they belong to the Parliament under Article 17 of the Constitution. ${ }^{54}$ Further, applicants claimed that the establishment of the Civil Protection Authority, an ad hoc and essentially executive body headed by the Minister of Interior and whose members were nominated by the government, violated the principle of separation of powers. The petitioners argued that the measures introduced in the Croatian legal system due to pandemic could be constitutional only upon the declaration of the state of emergency under Article 17 of the Constitution. ${ }^{55}$ They also claimed that Article 10 of the Law on Protection of Population from Infectious Diseases is unconstitutional (in discordance with Article 16 of the Constitution) as it does not envision any control-mechanism and the proportionality of the decisions of Civil Protection Authority, nor does it enlist the legitimate aims that the measures of the body could be counterbalanced with. The additional question raised by the petitioners concerned the decisions of the Civil Protection Authority (CPA) introduced before the amendments, which were legalized post-facto, retroactively, and which was already raised within scholarship. ${ }^{56}$

In its response, the government justified the decision to delegate the powers of introducing measures to fight the Covid-19 to the CPA by reliance on the principle of efficiency and proportionality, with the aim of protecting public health. ${ }^{57}$

Unlike the Serbian Constitution, which distinguishes the procedures of declaration of state of emergency and introduction of the measures for restriction of rights and freedoms, the Croatian Constitution does not mention the declaration of the state of emergency as such:

During a state of war or an immediate threat to the independence and unity of the State, or in the event of severe natural disasters, individual freedoms and rights guaranteed by the Constitution may be restricted. This shall be decided by the Croatian Parliament by a two-thirds majority of all members or, if the Croatian Parliament is unable to meet, at the proposal of the Government and upon the counter-signature of the Prime Minister, by the President of the Republic. ${ }^{58}$

According to this provision, the rights and freedoms of citizens can be restricted only on three constitutional grounds - state of war, immediate

54 U-I-1372/2020, para. 8.

55 Ibid. para. 9.

56 Gardašević, Đ., 2020, Pandemic and the Constitution of the Republic of Croatia, Informator, (https://informator.hr/strucni-clanci/pandemija-i-ustav-republike-hrvatske, 5. 11. 2020).

57 U-I-1372/2020, para. 13.

58 Article 17, Section 1. 
threat to the independence and unity of the state, and in the event of severe natural disasters. This section, textually interpreted, does not explicitly recognize the two-step procedure of emergency governance - declaration of emergency and the subsequent restriction of rights. However, if this norm is teleologically and systematically interpreted, it could be concluded that the power is vested in the Parliament. As the Parliament is vested with the power to restrict the individual freedoms and rights with the two-thirds majority, it is presumably also vested with the power, in the Schmittian sense, to decide on the exception and declare the state of emergency. However, since the Constitution of Croatia does not textually express this, the question of who can and should declare the state of emergency has been disputed among the constitutional judges themselves.

According to the majority opinion, the Constitutional Court has a power to review the decision of the Parliament to restrict human rights and freedoms as envisioned in Article 17, but "Constitutional Court is not competent to review whether or not the Croatian Parliament, in certain circumstances, notwithstanding whether those are enlisted in Article 17 or not as it is the case with COVID-19, will apply (or activate) Article 17 of the Constitution."59 Additionally, the Court asserted that "Constitutional Court is not competent to guide Croatian Parliament in choosing between two constitutional options of restriction of human rights and freedoms" ${ }^{60}$ By declaring its incompetence to review what constitutional arrangement should be applied in the circumstance of the pandemic, the Court tacitly asserted that the question of constitutional subsumption of "Schmittian facts" 61 to the constitutional framework of state of emergency under Article 17 falls outside the scope of judicial oversight. Yet, according to the dissenting opinion of judge Andrej Abramović, which was joined by judges Lovorka Kušan and Goran Selanec, this position of the Court is "simply untrue". ${ }^{62}$

The several claims expressed by three dissenters can be roughly summarized in the following way. Firstly, the dissenting judges have challenged the majority opinion that the Parliament may choose whether it will activate Article 17 or not, as explicitly stated in the majority opinion. The constitutional norms of Articles 16 and 17, as judge Abramović claims, are always active, and they should be applied if the de facto state

59 U-I-1372/2020, para. 27.

60 Ibid., para. 28.

61 For the definition of the "Schmittian fact" see: Jovanović, M., 2020, Ustavni sud u raljama karlšmitovskih pitanja, Peščanik, (https://pescanik.net/ustavni-sud-u-raljamakarlsmitovskih-pitanja/, 6. 11. 2020).

62 U-I-1372/2020, Dissenting Opinion of Judge Abramović, joined by Judges Kušan and Selanec. 
of emergency exists. ${ }^{63}$ Additionally, since the Croatian Constitution does not explicitly state which constitutional actor is authorized to declare a state of emergency, judge Abramović concluded that there was no need to declare it if it de facto exists. ${ }^{64}$ To support his arguments, the judge noted that the World Health Organization already in March declared the global pandemic and invited all the states to take "prompt action". He added that half of the EU Member States already declared a state of emergency and that the wording of the Article 22a ("specific circumstances involving an unpredictable or uncontrollable event or state endangering the lives and health of citizens") could be legitimately defined as natural disaster, which is one of three grounds for the declaration of the state of emergency as prescribed by Article 17. Further, the judge stressed that the Croatian Government itself debated on triggering Article $17 .{ }^{65}$ Finally, the dissenters added that from the perspective of the consequences of the introduction of a state of emergency and the severity of the measures needed to grapple with the pandemic, the two-thirds majority of the MP votes would be a more suitable solution even for the government itself, as the decisions reached by the two-thirds majority would be subject to lesser judicial scrutiny. The crucial difference between Article 16 and Article 17 is that under Article 17, the judicial standard is the propriety of the means (whether the means are curtailed to the exigencies of the state of emergency), while Article 16 requires the measures not only to be proper but also proportionate and necessary to achieve the legitimate aim. ${ }^{66}$ From all of the mentioned, judge Abramović, joined with judge Selanec and Kušan, concluded that Article 17 of the Croatian Constitution should have been applied. ${ }^{67}$

The paradox the Croatian Constitutional Court faced was the possibility that the introduction of a state of emergency could in practice provide more protection (due to the two-thirds threshold) for the constitutionally entrenched rights and freedoms than the rights limitation

63 Ibid.

64 "The Constitution does not prescribe which actor is authorized to declare state of emergency when it takes place. From that it could be concluded that there is no need to declare it if it de facto exists, although for the purpose of legal certainty, it would be better if the Constitution was amended in that regard. However, if the state of emergency de facto already exists, the government should act as prescribed by the Constitution." Ibid.

65 Ibid.

66 Ibid., see also: Selanec, N., 2020, (https://verfassungsblog.de/croatias-responseto-covid-19-on-legal-form-and-constitutional-safeguards-in-times-of-pandemic/, Croatia's Response to COVID-19: On Legal Form and Constitutional Safeguards in Times of Pandemic, The Verfassungsblog, 7. 11. 2020).

67 U-I-1372/2020, Judge Abramović, Kušan and Selanec. 
arrangement under Article 16, which applies during constitutional normalcy. However, strong arguments are deriving from the interpretation of the Croatian Constitution in favor of the claim that, ultimately, it is the Parliament, as the democratically elected branch of the government, to be the primary constitutional actor to assess (and not choose) whether the conditions for declaring the state of emergency as provided by Article 17 were present during Covid-19 pandemic. In addition, the severe effects of the Covid-19 pandemic on citizens' health could be a reasonable justification to introduce prompt and efficient regulation, which Article 17 legislation of two-thirds majority arguably would not be able to provide. In that sense, by deciding not to dispute the Parliament's decision not to invoke Article 17 arguably can hardly be perceived as unwarranted deference of the Court towards the Parliament or Executive. Nevertheless, the Croatian Constitutional Court did arguably demonstrate an unwarranted deferential approach in another manner - by missing the chance to lay out a clear doctrine on the separation of powers and set the standards under which the constitutional court's deference to other branches of government is justified under the Croatian Constitution. In order to reach this conclusion, it is useful to go a few steps back.

The constitutional arrangement of emergency powers under Article 17 of the Croatian Constitution puts forward Croatian Parliament as the primary actor authorized to restrict rights and freedoms under three grounds constituting emergency (state of war, imminent threat to the independence and unity of the state, and natural disaster) and only with the two-thirds majority which is demanding requirement of itself. Only if the Croatian Parliament cannot meet, that power shift to the President, with the prime minister's counter-signature. Secondly, the constitutional limitations of the Parliament's powers drawn from international standards demand that the measures restricting rights have to be curtailed to the emergency exigencies and prohibits the derogation of certain rights, following Article 4 of the International Covenant on Social and Political Rights (ICCPR). From the perspective of constitutional design, this arrangement of emergency powers leans towards a strong legislative model with prima facie low chances for the abuse of power by any constitutional actor. Precisely this was the legitimate reason for the dissenting judges to argue that the state of emergency should have been introduced, as the two-thirds majority provides space only for the limitation of rights and freedoms on which the high majority of the democratically elected representatives may agree upon. However, the viability of the two-thirds majority from the perspective of rights protection does 
not make the Parliament's decision not to introduce the emergency legislation with a higher threshold unconstitutional per se.

Today, the contemporaneous judicial review of emergency governance is not uncommon, especially on procedural grounds and after the state of emergency is lifted. This type of judicial review "primarily has educational benefits: it sets standards for future events". ${ }^{68}$ It could be argued that, from the perspective of the rule of law and the constitution itself, it is precisely the area in which the constitutional courts should set out strict standards for the government's actions. However, as András Sajó and Renáta Uitz note "contemporaneous judicial review of the declaration of emergency is a possibility in some countries, especially as far as the derogation from human rights is concerned, but experience shows that this is understandably extremely deferential." ${ }^{69}$ Even if the judicial deference is understandable in times of emergency, that does not mean it should not be justified from the constitutional perspective.

The problem in the Croatian case was that there was no declaration of the state of emergency to assess. If the Court went into merits on whether there were material conditions for departing from the state of normalcy, that would mean a grand departure from the deferential judicial approach. The instances of "judicial activism" in emergency cases, although extremely rare, can be found in comparative constitutional case law. The notable exception from the deferential approach goes back to the constitutional jurisprudence of Columbia from the early 1990s, where the Court actively engaged in the assessment of emergency powers and even went further to exercise "substantial control" of the state of emergency. ${ }^{70}$ The first case in which the Columbian Constitutional Court exercised the material control concerned the social state of emergency (which can be introduced on the grounds of economic crisis or natural disaster). ${ }^{71}$ The Court imposed a number of restrictions for the declaration of the state of emergency: the President had to prove that the facts he relied on when declaring the emergency were grave enough to depart from the constitutional normalcy, that he had little discretion when making that decision and

68 Sajó, A., Uitz, R., 2017, The Constitution of Freedom, Oxford Scholarship Online, p. 432.

69 Ibid.

70 "Material' or 'substantial' control, meaning that it was the duty of the court to analyze if the crisis was severe enough to justify the declaration of a state of emergency." Uprimny, R., The Constitutional Court and Control of Presidential Extraordinary Powers in Colombia, in: Gargarella, R., Gloppen, S., Skaar, E., (eds.), 2004, Democratization and the Judiciary. The Accountability Functions of Courts in New Democracies, Routledge, pp. 38-40.

71 Ibid. 
finally, that the ordinary legislation was not adequate to respond to the exigencies of the social crisis. ${ }^{72}$ Ultimately, the Court concluded that the President's decision to introduce the state of emergency was unjustified. In the following years, the Court applied this doctrine repeatedly. Although this approach got significant public support as an effective check on the emergency powers by the judicial branch of government, there was also significant backlash coming not only from the subsequent Presidents ${ }^{73}$ but also from some scholars who supported the Court, but claimed that it failed to develop a consistent doctrine or clear judicial standards within the material control of declaration of a state of emergency, which ultimately may lead to legal uncertainty regarding the effects of the Constitutional Court's jurisprudence. Ultimately, by engaging in the substantive reasons behind the declaration of the state of emergency, the Columbian Court risked undermining its authority if the case arose where the standards of their material review doctrine could not be consistently applied.

However, regardless of the theoretical position on whether a constitutional court as the guardian of the constitution should take a more deferential and activist approach in the assessment of the emergency governance, there are two important points of distinction between the material review of the declaration of emergency and the dilemma present in the analyzed case of the Croatian Constitutional Court. First, the Columbian Constitutional Court got an opportunity to engage in substantial assessment of the conditions for the declaration of the state of emergency only after the state of emergency was introduced (which in the Croatian case did not happen). Second, the constitutional arrangement of the state of emergency in Columbia is crucially different than the Croatian envisioned in Article 17. According to Article 215 of the Columbian Constitution, the power to declare the state of emergency is vested in the President (with co-signature of all the ministers), with stringent limitations to his emergency powers, most importantly, that the President's emergency decisions need to be justified (which leaves the space for the constitutional court to develop the material control of declaration of powers). In the Croatian case, the power to restrict rights and freedoms, both under Articles 16 and 17, is vested in the Parliament, which, as the elected branch of government, arguably enjoys substantial democratic legitimacy to decide when and under which conditions, following the constitutional framework, will

72 Ibid., p. 39.

73 President Uribe even proposed a constitutional amendment suggesting that the constitutional court's powers to exercise the material review of emergency powers should be restricted. Ibid. 
depart from the constitutional normalcy. Once it does so, the judicial review can and should serve as an effective check on its powers.

The Columbian experience shows that the courts may assert the power to assess the material conditions for the declaration of the state of emergency. Thus, the deference to the other branches of the government need not be justified by the lack of judicial standards. However, assessing the material conditions by a court may be warranted only once the state of emergency is in place. The assessment of the material conditions for introducing the state of emergency by a court before the declaration by democratically elected branches of the government suggests the overstepping of the limits of judicial power.

To conclude, even if the assumption of the Croatian judges who wrote dissenting opinion that the state of emergency de facto took place in practice proves valid, it would be rather exceptional, from the perspective of comparative constitutional law and constitutional theory on the separation of powers principle, for the constitutional court to a priori assess whether there was the need to depart from the "constitutional normalcy". ${ }^{74}$ In that sense, despite the strong and legitimate arguments of judge Abramović behind the claim that the state of emergency de facto took place and that there was the need for the higher threshold when restricting rights and freedoms during the Covid-19, the Croatian Constitutional Court's majority's deference on the question whether Article 17 should have been applied could be perceived as justified, in the light of the separation of powers principle. Nevertheless, the fact that the Court explicitly demonstrated deference but failed to provide clear legal standards and layout the doctrine on the principle of separation of powers to support its claim that it is not competent to assess whether the material conditions for triggering Article 17 were in place, ultimately undermines the authority of the Constitutional Court as the guardian of the Constitution. Still, the Croatian Constitutional Court referred back to the legislator who is authorized to decide on the case of emergency by the constitution. This is a differentia specifica in the comparison of the Serbian and Croatian case. Serbian Constitutional Court legitimized the complete shift of power to the executive (despite the legislative constitutional design of emergency powers), thereby confirming the Neo-Schmittian model. On the other hand, the Croatian Court demonstrated its reference to the Parliament, which is a constitutionally

74 For the limits and criticism of the judicial review and the strong role of the courts see: Waldron, J., 2006, The Core of the Case Against Judicial Review, Yale Law Journal, Vol. 115, No. 6, p. 1346. 
authorized body to decide on the state of emergency. Although this example does not reflect a perfect Madisonian model, the power during times of emergency still remains within the constitutionally envisioned branch of the government - the Parliament.

\section{Conclusion}

The deference of a constitutional court in times of an emergency, as the constitutional theory and comparative jurisprudence point out, is not unusual as such or per se unwarranted. However, the role of the constitutional court as the guardian of the constitution and the ultimate interpreter of the constitutional text is to put forward clear, the coherent doctrine of both the state of emergency and the principle of separation of powers, which will serve as guidance and limits to the constitutionally authorized state actors when faced with a crisis such as the Covid-19 pandemic. According to Ginsburg's and Versteeg's distinction, this would represent an example of the Madisonian model of emergency powers. The Serbian, and to a lesser extent, the Croatian Constitutional Court arguably failed to meet the standards of this model. The Madisonian model does not, by definition, require the courts to annul acts of other branches of emergency governance or engage in judicial activism but to set the constitutional standards under which those acts will be assessed. As Lord Rodger put it: "Due deference does not mean abasement." 75 Under a coherent, robust, and consistently applied doctrine of deference, the state of exception would indeed remain within the limits of the legal order and bound all the branches of the government not to overstep them.

\section{BIBLIOGRAPHY}

1. Beširević, V., 2016, A jedan razlog menja sve: kontrola ustavnosti Briselskog sporazuma u svetlu doktrine političkog pitanja, Hereticus, 1-2.

2. Beširević, V. et al., Član 15 - Odstupanje u vanrednim okolnostima, in: Beširević et al. (eds.), 2017, Komentar Konvencije za zaštitu ljudskih prava i osnovnih sloboda, Službeni glasnik.

3. Bjørnskov, C., Voigt, S., 2018, The Architecture of Emergency Constitutions, International Journal of Constitutional Law, Vol. 16, No. 1.

4. Dyzenhaus, D., 2006, The Constitution of Law - Legality in a Time of Emergency, Cambridge University Press.

75 A v. Secretary of State for the Home Department [2005] AC 68, p. 158. See also: Dyzenhaus, D., 2012, p. 457. 
5. Dyzenhaus, D., States of Emergency, in: Sajó, A., Rosenfeld, M., (eds.), 2012, The Oxford Handbook of Comparative Constitutional Law, Oxford University Press.

6. Ferejohn, J., Pasquino, P., 2004, The Law of the Exception: A Typology of Emergency Powers, International Journal of Constitutional Law, Vol. 2, No. 2.

7. Gardašević, Đ., 2020, Pandemic and the Constitution of the Republic of Croatia, Informator, (https://informator.hr/strucni-clanci/pandemija-i-ustav-republikehrvatske, 5. 11. 2020).

8. Gerards, J., 2018, Margin of Appreciation and Incrementalism in the Case Law of the European Court of Human Rights, Human Rights Law Review, Vol. 18, No. 3.

9. Greene, A., 2020, States should declare a State of Emergency using Article 15 ECHR to confront the Coronavirus Pandemic, Strasbourg Observers, (https://strasbourgobservers.com/2020/04/01/states-should-declare-a-state-of-emergency-using-article-15-echr-to-confront-the-coronavirus-pandemic/, 7. 10. 2020).

10. Greene, A., 2018, Permanent States of Emergency and the Rule of Law: Constitutions in an Age of Crisis, Hart Publishing.

11. Ginsburg, T., Versteeg, M., 2020, The Bound Executive: Emergency Powers During the Pandemic, Virginia Public Law and Legal Theory Research Paper No. 2020-52, Public Law Working Paper No. 747, University of Chicago.

12. Lock, J., 1980, Macpherson, C.B. (eds.), 1980, Second Treatise of Government, Hackett Publishing.

13. Lurie, G., Introduction: Emergency, Exception and Normalcy, in: Albert, R., Roznai, Y. (eds.), 2020, Constitutionalism Under Extreme Conditions, Springer.

14. Jovanović, M., 2020, Ustavni sud u raljama karlšmitovskih pitanja, Peščanik, (https://pescanik.net/ustavni-sud-u-raljama-karlsmitovskih-pitanja/, 6. 11. 2020).

15. OSCE Office for Democratic Institutions and Human Rights, 2020, The Functioning of Courts in the Covid-19 Pandemic: A Primer (2 November, 2020).

16. Posner, A., Vermuele, A., 2007, Terror in the Balance: Security, Liberty and the Courts, New York, Oxford University Press.

17. Posner, E., Vermuele, A. 2011, The Executive Unbound: After the Madisonian Republic, Oxford University Press.

18. Rask Madsen, M., 2018, Rebalancing European Human Rights: Has the Brighton Declaration Engendered a New Deal on Human Rights in Europe?, Journal of International Dispute Settlement, Vol. 9, No. 2.

19. Sajó, A., Uitz, R., 2017, The Constitution of Freedom, Oxford Scholarship Online.

20. Selanec, N., 2020, (https://verfassungsblog.de/croatias-response-to-covid-19-onlegal-form-and-constitutional-safeguards-in-times-of-pandemic/, Croatia's Response to COVID-19: On Legal Form and Constitutional Safeguards in Times of Pandemic, The Verfassungsblog, 7. 11. 2020).

21. Spaić, B., 2020, Literarni dometi rešenja IUo-42/2020, Center for Judicial Research Cepris, (https://www.cepris.org/licni-stavovi/literarni-dometi-resenjai\%D1\%83\%D0\%BE-42-2020dr/, 12. 11. 2020).

22. Schmitt, C., Schwab, G. (transl.), 2006, Political Theology: Four Chapters on the Concept of Sovereignty, University of Chicago Press. 
23. Uprimny, R., The Constitutional Court and Control of Presidential Extraordinary Powers in Colombia, in: Gargarella, R., Gloppen, S., Skaar, E., (eds.), 2004, Democratization and the Judiciary. The Accountability Functions of Courts in New Democracies, Routledge.

24. Waldron, J., 2006, The Core of the Case Against Judicial Review, Yale Law Journal, Vol. 115, No. 6.

\section{Legal ACts}

1. Constitution of the Republic of Serbia, Official Gazette of RS, No. 98/06.

2. Constitution of the Republic of Croatia, National Gazette of RC, No. 56/90, 135/97, 113/00, 28/01, 76/10, 5/14.

3. Constitution of the Republic of France of 4 October 1958, Journal Officiel de la République Française 9151-9173.

4. International Covenant on Civil and Political Rights, 16 December 1966, United Nations, Treaty Series, (https://www.refworld.org/docid/3ae6b3aa0.html, 1. 4. 2021).

5. Order of the Minister of Health on the declaration of the COVID-19 Pandemic of March 19, 2020, Official Gazette of RS, No. 37/2020-08.

6. The Law Amending the Law on the Civil Protection System, National Gazette of $R C$, No. 31/20.

7. The Law on Disaster Risk Reduction and Emergency Management, Official Gazette of RS, No. 87/18.

8. The Law on the Protection of Population from Infectious Diseases, National Gazette of $R C$, No. 47/20.

9. The Law on the Protection of the Population from Infectious Diseases, Official Gazette of RS, Nos. 15/16, 68/20, 136/20.

10. The Law on Public Health, Official Gazette of RS, No. 15/16.

\section{Case LaW}

1. A v. Secretary of State for the Home Department, [2005] AC 68.

2. Constitutional Court of the Republic of Serbia, Ruling on Dismissal IUo-42/2020 of May 22, 2020, Official Gazette of RS, No. 77/2020.

3. The Constitutional Court of Croatia, the Ruling on Dismissal U-I-1372/2020 of September 14, 2020, National Gazette of RC, No. 105/20. 


\title{
OGRANIČENA VLAST ZA VREME VANREDNOG STANJA: KRATKI OSVRT NA ODGOVOR DRŽAVA JUGOISTOČNE EVROPE NA PANDEMIJU KOVID-19 VIRUSA
}

\author{
Teodora Miljojković
}

\begin{abstract}
APSTRAKT
Oslanjajući se na teorijsku podelu na Medisonov i Šmitov model vlasti za vreme vanrednog stanja, ovaj rad istražuje do koje mere su ustavni sudovi dve zemlje jugoistočne Evrope (Srbija i Hrvatska) efikasno ograničile izvršnu vlast pri uvođenju mera radi suzbijanja pandemije kovida 19. Posebna pažnja rada posvećena je pitanju na koji način su ustavni sudovi doktrinarno odgovorili na pitanje da li je pandemija kovida 19 osnov za proglašenje vanrednog stanja. Dileme sa kojima su se ustavne sudije susrele u svojim odlukama oslikavaju neka od gorućih pitanja teorije o ustavnom režimu vanrednog stanja: (1) Da li je izvršna vlast de facto šmitovski suveren koji odlučuje o izuzetku, čak i kada ustav propisuje suprotno? (2) Da li sudovi, u skladu sa istorijski ustaljenom praksom, treba da pokažu posebnu naklonost prema drugim granama vlasti pri suzbijanju kriza kao što je pandemija kovida 19? (3) Da li su sudovi u mogućnosti da procene faktičko prisustvo ustavom predviđenih uslova za proglašenje vanrednog stanja, to jest da vrše kako formalnu tako i supstantivnu kontrolu ustavnosti proglašenja vanrednog stanja? U radu se zaključuje da su Srbija i Hrvatska, propuštanjem da ustanove jasnu doktrinu vanrednog stanja, neuspešno ograničile druge grane vlasti pri odgovoru na pandemiju kovida 19. Ustavni sud Srbije je u svojoj odluci potvrdio neošmitovski model, koji pretpostavlja da je u vreme krize opravdana koncentracija vlasti u izvršnim organima. S druge strane, Ustavni sud Hrvatske mogao je da učini više u afirmaciji Medisonovog modela, koji pretpostavlja sistem teže i protivteže, kao i uzajamnu saradnju među svim granama vlasti.
\end{abstract}

Ključne reči: pandemija kovida 19, ustavno sudstvo, vanredno stanje, kontrola ustavnosti.

Article History:

Received: 23 November 2020

Accepted: 11 June 2021 